\title{
Enhanced membrane-type 1 matrix metalloproteinase expression by hyaluronan oligosaccharides in breast cancer cells facilitates CD44 cleavage and tumor cell migration
}

\author{
CHANG-I KUNG $^{1 *}$, CHENG-YI CHEN ${ }^{1 *}$, CHIH-CHANG YANG $^{1}$, \\ CHENG-YU LIN $^{1}$, TIEN-HUA CHEN $^{1,2}$ and HWAI-SHI WANG ${ }^{1}$ \\ ${ }^{1}$ Institute of Anatomy and Cell Biology, School of Medicine, National Yang Ming University, Taipei; \\ ${ }^{2}$ Department of Surgery, Veterans General Hospital, Taipei, Taiwan, R.O.C.
}

Received June 18, 2012; Accepted August 3, 2012

DOI: 10.3892/or.2012.1993

\begin{abstract}
Hyaluronan (HA), a component of the extracellular matrix, plays an important role in cell-cell adhesion and cell migration. Membrane type 1-matrix metalloproteinase (MT1-MMP) is often expressed in invasive cancer cells. CD44, a transmembrane receptor for HA, is implicated in various adhesion-dependent cellular processes including cell migration, tumor cell metastasis and invasion. Previous studies have shown that CD44 is highly expressed in cancer cells and may be proteolytically cleaved at the ectodomain by MT1-MMP; this process of inducing CD44 cleavage plays a critical role in cancer cell migration. We hypothesized that HA modulates MT1-MMP expression to facilitate breast cancer cell migration. Flow cytometry, real-time PCR, western blotting and immunofluorescence staining were used to quantify HA-induced MT1-MMP expression in breast cancer cells. In order to validate the relevance of cell migration and HA-induced MT1-MMP, we analyzed the cell migration via Matrigel-coated transwell. We found that after HA oligosaccharide (6.5 kDA) stimulation, MT1-MMP expression in the membrane of breast cancer cells was increased. In response to HA oligosaccharide stimulation, significant upregulation of MT1-MMP mRNA occurred. Our data also provide evidence that HA oligosaccharide enhances MT1-MMP; the elevated expression of MT1-MMP confers enhanced CD44 cleavage and cell migration. In conclusion, we have identified a new function of HA in the induction of MT1-MMP expression in breast cancer cell lines and CD44 cleavage to increase cell migration during the invasion process. The HA oligosaccha-
\end{abstract}

Correspondence to: Dr Hwai-Shi Wang, Institute of Anatomy and Cell Biology, School of Medicine, National Yang Ming University, Taipei, Taiwan, R.O.C.

E-mail: hswang@ym.edu.tw

*Contributed equally

Key words: hyaluronan, CD44, membrane type-1 matrix metalloproteinase, tumor metastasis, breast cancer cell ride-induced MT1-MMP expression in breast cancer cells may be a critical step in the formation of metastatic colonies.

\section{Introduction}

CD44, a hyaluronan (HA) receptor, serves as an adhesion molecule in cell-substrate and cell-cell interactions, lymphocyte recruitment to inflammatory sites and tumor metastasis (1-4). CD44 isoforms are generated from a single gene by messenger RNA alternative splicing of at least 12 exons (5). The size of the CD44 molecule ranges from the standard $85-95 \mathrm{kDa}$ form (CD44s) to larger variant isoforms (CD44v) of $200 \mathrm{kDa}$ or more. The differences in size are partly due to post-translational modifications, as all isoforms of CD44 are highly glycosylated (6). The functional characterization of the different isoforms of this family remains limited.

Invasion is a critical step for metastasis. Tumor cell invasion involves cell adhesion to the extracellular matrix, degradation of extracellular matrix components, tumor cell motility and cell detachment (7). CD44 is expressed in many types of invasive tumor cells $(2,4)$. It has been shown in animal models that the injection of reagents that interfere with the binding of CD44 to its ligand inhibits local tumor growth and metastatic spread $(8,9)$. Soluble CD44 can be shed from cell surfaces through a proteolytic process by metalloproteinase $(10,11)$. This cleavage is followed by $\gamma$-secretase-dependent release of CD44 intracellular domain (ICD) (12). This proteolytic cleavage of CD44 is involved in tumor invasion and metastasis (10). During tumor metastasis, cells detach from the primary tumor, penetrate the basement membrane into the connective tissue, and invade adjacent structures, including lymph and blood vessels. The tumor cells are subsequently transported to metastatic sites via the lymph and/or blood. However, the mechanisms by which CD44 promotes tumor metastasis are poorly understood.

Matrix metalloproteinases (MMPs) are a group of proteases that are involved in extracellular matrix degradation; the functioning of these proteases requires the presence of zinc. Since MMPs degrade extracellular matrix, they participate in tumor cell invasion and migration (13). The MMP family is currently divided into two categories: soluble-type MMPs 
and membrane-type MMPs (MT-MMPs) $(14,15)$. One of these proteins, MT1-MMP, is often-expressed in invasive cancer cells and in endothelial cells during angiogenesis $(16,17)$ and its substrates include type I, II and III collagen, laminin-1, -5 , vitronectin, fibronectin and aggrecan (18). MT1-MMPs also activate other proMMPs, including proMMP-2 and proMMP-13 $(19,20)$. The expression of MT1-MMP on the cell surface may trigger various activation cascades. Research has shown that the extracellular domain of CD44 undergoes cleavage on the surface of cancer cells and this cleavage process plays a decisive role during tumor cell migration (21). This process of inducing CD44 de-adhesion through metalloproteinase interaction appears to be significantly involved in cell movement.

In this report, we have identified a new function for HA, its involvement in the induction of MT1-MMP expression in breast cancer cells and the subsequent mediation of cellular migration during the invasion process. Based on these new findings, we suggest that the activation signals resulting from HA stimulation may be involved in tumor cell metastasis. We propose that one function of HA oligosaccharides in tumor cells may be to induce MT1-MMP expression, which, at least for a number of tumor cell types, may be a critical step in the formation of metastatic colonies.

\section{Materials and methods}

Cell culture. The human breast carcinoma cell lines, MDA-MB-435s and MDA-MB-231, were obtained from the Food Industry Research and Development Institute (Hsinchu, Taiwan). Cells were grown in Leibovitz's L-15 medium supplemented with $15 \%$ fetal bovine serum (FBS; HyClone, Logan, UT, USA), $10 \mu \mathrm{g} / \mathrm{ml}$ of insulin, $100 \mathrm{U} / \mathrm{ml}$ of penicillin, and $100 \mu \mathrm{g} / \mathrm{ml}$ of streptomycin at $37^{\circ} \mathrm{C}$ in a humidified atmosphere of $5 \% \mathrm{CO}_{2}$.

Antibodies. Mouse monoclonal antibody against human MT1-MMP and rabbit monoclonal antibody (Ab) against CD44 were purchased from R\&D Systems (Minneapolis, $\mathrm{MN}$, USA). Mouse monoclonal Ab against CD44 and horseradish peroxidase-conjugated goat anti-mouse secondary $\mathrm{Ab}$ were both purchased from NeoMarkers (Fremont, CA, USA). Rabbit polyclonal Ab against MT1-MMP and rhodamineconjugated goat anti-rabbit secondary $\mathrm{Ab}$ was purchased from Chemicon International, Inc. (San Diego, CA, USA). FITCconjugated bovine anti-mouse secondary $\mathrm{Ab}$ was purchased from Santa Cruz Biotechnology (Santa Cruz, CA, USA).

Flow cytometry. MDA-MB-435s cells were cultured in a serum-free medium (Leibovitz's L-15 medium) overnight and then HA was added $(0.05 \mathrm{mg} / \mathrm{ml} ; 0.5 \mathrm{mg} / \mathrm{ml})$ for $36 \mathrm{~h}$. Next, the cells were trypsinized and suspended in Leibovitz's L-15 medium at a concentration of $5 \times 10^{6}$ cells $/ \mathrm{ml}$, and then a 1-ml sample was incubated for $45 \mathrm{~min}$ at $4^{\circ} \mathrm{C}$ with $150 \mu \mathrm{l}$ of various non-labeled mouse anti-human antibodies followed by fluorescein isothiocyanate (FITC)-conjugated anti-mouse immunoglobulin $\mathrm{G}(\mathrm{IgG})$ antibodies $(10 \mathrm{mg} / \mathrm{ml})$ for $1 \mathrm{~h}$ at room temperature. Finally, the cells were washed twice with phosphate-buffered saline (PBS; pH 7.4), centrifuged, and fixed in $1.5 \mathrm{ml}$ of $4 \%$ paraformaldehyde. Control samples were incubated with PBS instead of primary antibody. A FACScan machine (Becton-Dickinson, Franklin Lakes, NJ, USA) was used to analyze antibody binding.

Western blot analysis. For immunoblotting on polyvinylidene difluoride (PVDF) membranes (Amersham; Piscataway, NJ, USA), cells per treatment group were pooled, rinsed briefly with PBS, then lysed on ice for $10 \mathrm{~min}$ in $1 \mathrm{ml}$ of PBS containing $1 \%$ sodium dodecyl sulfate, $0.5 \mathrm{mM}$ phenylmethylsulfonyl fluoride, $10 \mu \mathrm{g} / \mathrm{ml}$ leupeptin, $10 \mu \mathrm{g} / \mathrm{ml}$ aprotinin, $5 \mu \mathrm{g} / \mathrm{ml}$ pepstatin, $10 \mu \mathrm{g} / \mathrm{ml}$ soybean trypsin inhibitor, and $0.5 \mathrm{mM}$ dithiothreitol. Following centrifugation for $20 \mathrm{~min}$ at $1,300 \mathrm{~g}$ and $4^{\circ} \mathrm{C}$, the supernatant was removed and centrifuged at $6,000 \mathrm{~g}$ for $1 \mathrm{~h}$ at $4^{\circ} \mathrm{C}$. The final supernatant was used as the cytosolic fraction and the pellet as the membrane fraction. Equal amounts (50 $\mu \mathrm{g}$ of protein) of the membrane fractions or cytosolic fractions were run on $10 \%$ polyacrylamide gels and transferred to PVDF membranes in a transfer buffer [4 parts $25 \mathrm{mM}$ Tris/200 mM buffer ( $\mathrm{pH}$ 8.0) and 1 part methanol]. The membranes were then blocked for $1 \mathrm{~h}$ at room temperature with $50 \mathrm{mM}$ Tris $\mathrm{HCl}, 150 \mathrm{mM} \mathrm{NaCl}, 0.05 \%$ Tween-20 [Tris buffered-saline with Tween-20 (TBST), pH 7.0], containing $5 \%$ non-fat dry milk, and then incubated overnight at $4^{\circ} \mathrm{C}$ with the primary Ab. The membranes were then washed with TBST and exposed to the horseradish peroxidase-conjugated secondary $\mathrm{Ab}$ for $1 \mathrm{~h}$ at room temperature. The bound $\mathrm{Ab}$ was detected by the enhanced chemiluminescence method (Perkin-Elmer Life Sciences, Waltham, MA, USA).

RNA extraction and real-time polymerase chain reaction analysis. Total RNA was extracted from both untreated (control) and treated cells using RNeasy purification reagent (Qiagen; Valencia, CA, USA) and then a sample ( $1 \mu \mathrm{g})$ was reverse transcribed with M-MLV reverse transcriptase for $30 \mathrm{~min}$ at $42^{\circ} \mathrm{C}$ in the presence of oligo-dT primer. PCR was performed using specific primers designed from the published sequence of each cDNA as follows; the oligonucleotides (sense 5'-GTGATGGATGGATA CCCAATGC-3' and antisense 5'-GAACGCTGGCAGTAAA GCAGTC-3') corresponding to human MT1-MMP were used for specific amplification of a $786 \mathrm{bp}$ fragment of MT1-MMP mRNA. The initial temperature for the RT-PCR was $95^{\circ} \mathrm{C}$ for $5 \mathrm{~min}$, followed by 35 cycles of denaturation at $95^{\circ} \mathrm{C}$ for $30 \mathrm{sec}$, annealing at $55^{\circ} \mathrm{C}$ for $30 \mathrm{sec}$, and elongation at $72^{\circ} \mathrm{C}$ for $30 \mathrm{sec}$, with an additional 7 -min incubation at $72^{\circ} \mathrm{C}$ after completion of the last cycle. To exclude the possibility of contaminating the genomic DNA, the PCRs were also run without reverse transcriptase. The amplified cDNA was separated by electrophoresis through a $2 \%$ agarose gel, stained, and photographed under ultraviolet light. cDNA was used for PCR with specific primers in the presence of SYBR-Green I (LightCycler ${ }^{\circledR}$-FastStart DNA Master SYBR Green I; Roche, Basel, Switzerland). The sequences of the primers were: MT1-MMP forward, CGCTA CGCCATCCAGGGTCTCAAA, reverse, CGCTCATCAT CGGGCAGCACAAAA; GAPDH forward, CACCATCTT CCAGGAGCGAG, reverse, TCACGCCACAGTTTCCCGGA (Mission Biotech, Taiwan). A LightCycler ${ }^{\circledR} 480$ (Roche Diagnostics, Indianapolis, IN, USA) was used for real-time PCR.

Immunofluorescence stain and confocal laser scanning microscopic analysis. Breast cancer cells $\left(1 \times 10^{5}\right)$ were cultured on glass coverslips, serum-starved for $3 \mathrm{~h}$, and then treated with 
HA for various times. Following incubation, the cells were fixed in $4 \%$ paraformaldehyde for 15 min, washed with PBS, and pre-incubated in blocking solution (5\% non-fat milk in PBS) for $15 \mathrm{~min}$. After being washed with PBS, the cells were incubated with diluted anti-MT1-MMP monoclonal (m) Ab (1:500) or anti-CD44 mAb (1:500) in PBS for $60 \mathrm{~min}$ at room temperature. After washing with PBS, the cells were incubated with diluted FITC-conjugated secondary antibody or rhodamine-conjugated secondary antibody for $60 \mathrm{~min}$ at room temperature. The samples were then washed with PBS and mounted in a mounting medium (Vector; North Hollywood, CA, USA) and visualized using a confocal microscope (Leica; Wetzlar, Germany) with a 100/1.30 oil immersion objective and an appropriate filter. There was negligible immunofluorescence in the controls without primary antibodies.

Migration assay. The migration assay used was a transwell, the upper chamber of which consisted of cell culture inserts coated with $50 \mu \mathrm{l}$ of Matrigel at $37^{\circ} \mathrm{C}$ in an incubator overnight. The wells were washed 3 times with PBS. Sub-confluent breast cancer cell lines were trypsinized and re-suspended in a cell culture medium containing 5\% FBS. Then, $1 \times 10^{5}$ cells were added to the upper chamber and incubated overnight at $37^{\circ} \mathrm{C}$ in a humidified $5 \% \mathrm{CO}_{2}$ environment. Subsequently, cells were starved for $12 \mathrm{~h}$, and MT1-MMP specific Abs or MMP inhibitors were added to the cells for $1 \mathrm{~h}$ before treating the cells with HA for $60 \mathrm{~h}$. Cells that had invaded through the matrix and become adherent to the undersurface of the filter were quantified using Hoechst stain and observed with a fluorescence microscope.

Statistical analysis. The results are expressed as the mean \pm standard deviation (SD) of at least 3 experiments and comparisons were analyzed by one-way ANOVA. A P-value $<0.05$ was considered to indicate a statistically significant difference.

\section{Results}

Effects of HA on MT1-MMP expression on MDA-MB-435s cells. In order to observe the effect of HA on MT1-MMP expression following stimulation, MDA-MB-435s cells were treated for different times with $17,5.6$ and $6.5 \mathrm{kDa} \mathrm{HA}(0.05 \mathrm{mg} / \mathrm{ml}$ or $0.5 \mathrm{mg} / \mathrm{ml}$ ) (Fig. 1). HA $5.6 \mathrm{kDa}$ and $6.5 \mathrm{kDa}(0.5 \mathrm{mg} / \mathrm{ml})$ stimulation after $36 \mathrm{~h}$ revealed an increased expression of MT1-MMP on the cell membrane (Fig. 1A and B). This result showed that HA oligosaccharide (5.6 and $6.5 \mathrm{kDa})$ stimulation of MDA-MB-435s cells induced a significant amount of MT1-MMP expression on the cell membrane. Thus, $6.5 \mathrm{kDa}$ HA was used in the following experiments.

Immunofluorescence observation of CD44 and MT1-MMP expression following HA stimulation. We further investigated the link between CD44 and HA-induced MT1-MMP expression. After $36 \mathrm{~h}$ of HA stimulation, MDA-MB-435s cells were fixed, blocked, treated with mouse anti-CD44 mAb, rabbit anti-MT1-MMP polyclonal Ab, FITC-conjugated bovine anti-mouse $\mathrm{Ab}$, and rhodamine-conjugated goat anti-rabbit $\mathrm{Ab}$. The cells were then mounted and placed under a confocal microscope for observation. The results show that under normal conditions in MDA-MB-435s cells, the CD44 receptor
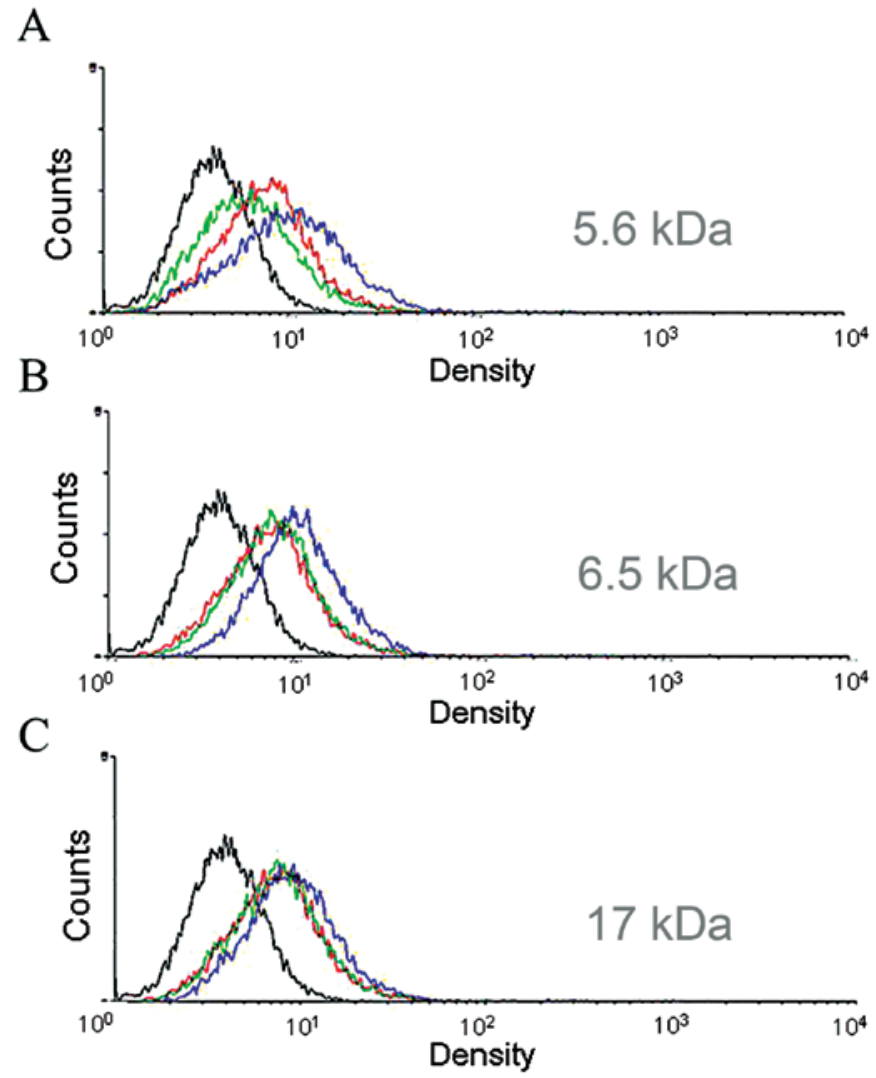

Figure 1. Hyaluronan-induced MT1-MMP expression on breast cancer cells. MDA-MB-435s breast cancer cells were serum-starved for $3 \mathrm{~h}$ and then treated with a control medium or medium with different concentrations of HA $(0.05 \mathrm{mg} / \mathrm{ml}$ or $0.5 \mathrm{mg} / \mathrm{ml})$ for $36 \mathrm{~h}$. The expression of MT1-MMP observed after (A) $5.6 \mathrm{kDa}$, (B) $6.5 \mathrm{kDa}$, and (C) $17 \mathrm{kDa} H A$ treatments. Flow cytometry showed that both 5.6 and $6.5 \mathrm{kDa} \mathrm{HA}$ at the concentration of $0.5 \mathrm{mg} / \mathrm{ml}$ may induce MT1-MMP expression in breast cancer cells. Black, negative control; red, control; green, HA treated $(0.05 \mathrm{mg} / \mathrm{ml})$; blue, HA treated $(0.5 \mathrm{mg} / \mathrm{ml})$.

was localized on the cell membrane and small amounts of MT1-MMP were localized in the cytosol (Fig. 2A). After HA stimulation for $36 \mathrm{~h}$, the expression of MT1-MMP increased on the cell membrane and colocalized with CD44 (Fig. 2B).

Gene expression levels in HA treated breast cancer cells. To determine whether HA has an effect on MT1-MMP expression, the expression levels of the MT1-MMP gene were examined by real-time PCR. As shown in Fig. 3, real-time PCR was used to quantify the gene expression levels of HA-treated cells compared to the control. For both MDA-MB-435s and MDA-MB-231 cells, mRNA levels for the MT1-MMP were significantly increased in HA-treated cells at $6 \mathrm{~h}$ (Fig. 3). Thus, $\mathrm{HA}$ is capable of inducing breast cancer cells which express the MT1-MMP gene.

The effects of cycloheximide on HA-induced MT1-MMP expression and CD44 cleavage on the cell membrane. Western blot analysis revealed that when the MDA-MB-435s (Fig. 4A-C) and MDA-MB-231 cells (Fig. 4D-F) were incubated with HA, MT1-MMP expression was increased. When the cells were pre-treated with cycloheximide and then stimulated with HA for 12,24 and $36 \mathrm{~h}$, the expression of MT1-MMP was decreased (Fig. 4A, B, D and E). Moreover, 

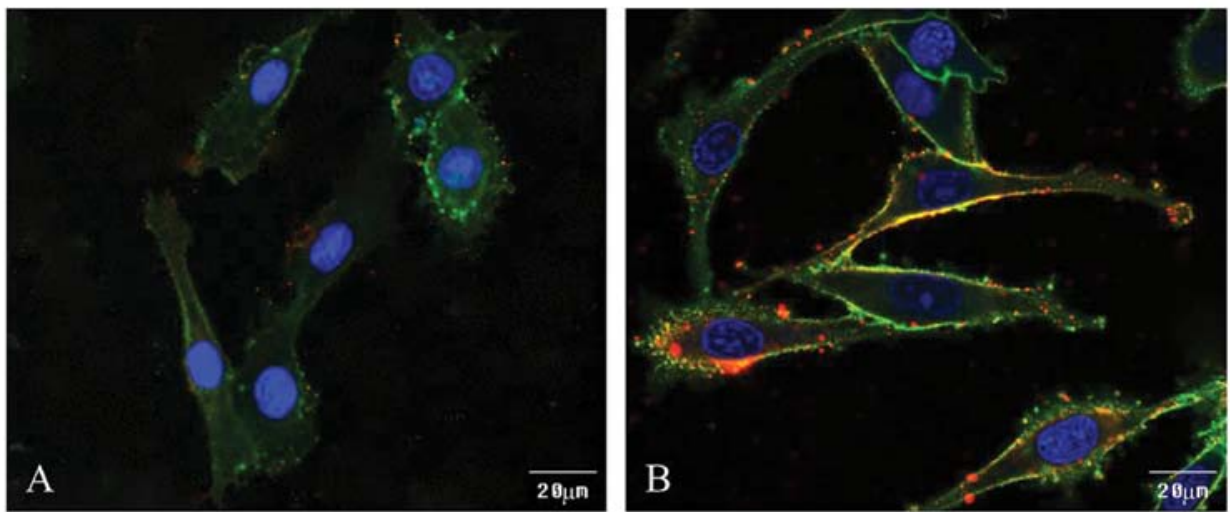

Figure 2. Double immunofluorescence staining of MT1-MMP and CD44 in MDA-MB-435s cells. Immunofluorescence staining of CD44 and MT1-MMP in MDA-MB-435s cells were observed using confocal microscopy. Cells with and without $6.5 \mathrm{kDa} \mathrm{HA}(0.5 \mathrm{mg} / \mathrm{ml})$ treatment stained with anti-MT1-MMP mAb (A) Control; (B) after HA-treatment for $36 \mathrm{~h}$, MT1-MMP was colocalized with CD44 on the cell membrane. CD44 staining (green), MT1-MMP staining (red) and nucleus (blue). Scale bar, $20 \mathrm{~mm}$.

A

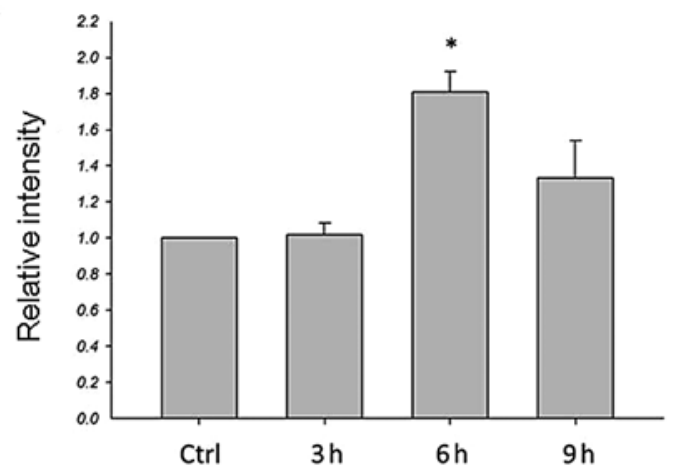

$\mathrm{B}$

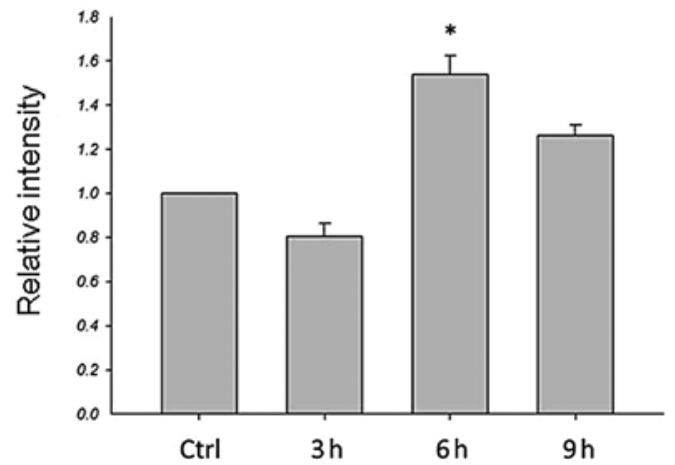

Figure 3. Real-time PCR analyses for the expression levels of the MT1-MMP gene. MDA-MB-435s and MDA-MB-231 cells were incubated in a serumfree medium for $3 \mathrm{~h}$ and then treated with a control medium or a medium with $6.5 \mathrm{kDA} H A(0.5 \mathrm{mg} / \mathrm{ml})$ for different time periods as indicated. Real-time PCR analyses for the expression levels of MT1-MMP in (A) MDA-MB-435s cells and (B) MDA-MB-231. Results are the means \pm SEMs of 4 experiments. ${ }^{*} \mathrm{P}<0.05$ compared to the control.

after HA treatment for 12, 24 and $36 \mathrm{~h}$, the CD44 ICD was increased after $12 \mathrm{~h}$ of stimulation (Fig. 4A, C, D and F). When cells were pre-treated with cycloheximide, the ICDs were reduced (Fig. 4A, C, D and F). These results further confirmed that HA induced the expression of MT1-MMP through protein synthesis. Moreover, HA-induced MT1-MMP was involved in the process of CD44 cleavage.
Invasiveness of breast cancer cells determined by migration assay following HA stimulation. Penetration of the cells through the Matrigel has been suggested to be similar to the invasive activities that occur during the metastatic process in vivo. A transwell coated with Matrigel was adopted to study the invasive behavior of the breast cancer cells. MDA-MB435s cells were pre-treated with MT1-MMP specific antibody or MMP inhibitor for $1 \mathrm{~h}$, then stimulated with or without HA for $60 \mathrm{~h}$, each individual well was followed to count the cells that had migrated through the membrane. MDA-MB-435S cells pre-treated with MT1-MMP specific antibody or MMP inhibitor reduced cell migration (Fig. 5).

\section{Discussion}

Matrix metalloproteinases (MMPs) comprise a family of zinc-dependent edopeptidases that can cleave virtually any component of the extracellular matrix (18) and play an important role in cancer cell invasion and metastasis (18). During metastasis, cancer cells break down the extracellular matrix to clear the path for movement, and then enter the blood vessels or the lymphatics (18). Membrane type-MMPs are a small group in the MMP family, consisting of six known members. Membrane type-MMPs are located on cell surfaces and degrade protein (22). Membrane type-MMPs are found in a number of different cancer cells and they are capable of breaking down extracellular matrix molecules, such as collagen type I and III, fibronectin, laminin-1 and -5 and aggrecan $(15,23)$.

Hyaluronan (HA) generally exists as a high molecular mass polymer (in excess of $1,000 \mathrm{kDa}$ ) as a component of the extracellular matrix under physiologic conditions (24). Lower molecular mass HA has been detected in association with certain pathologic conditions, such as inflammation (25) and tumors (26-28). The low molecular mass HA fragments induce a variety of biological events, such as cell proliferation (28) and angiogenesis (29). High levels of angiogenic HA fragments have been detected in several types of human tumor, such as bladder (28), prostate (30) and mesothelioma cancer (26). High levels of hyaluronidase activity are also found in prostate and bladder cancers $(30,31)$, which generate HA fragments. It is possible that the autoregulatory degradation of HA in tumor 

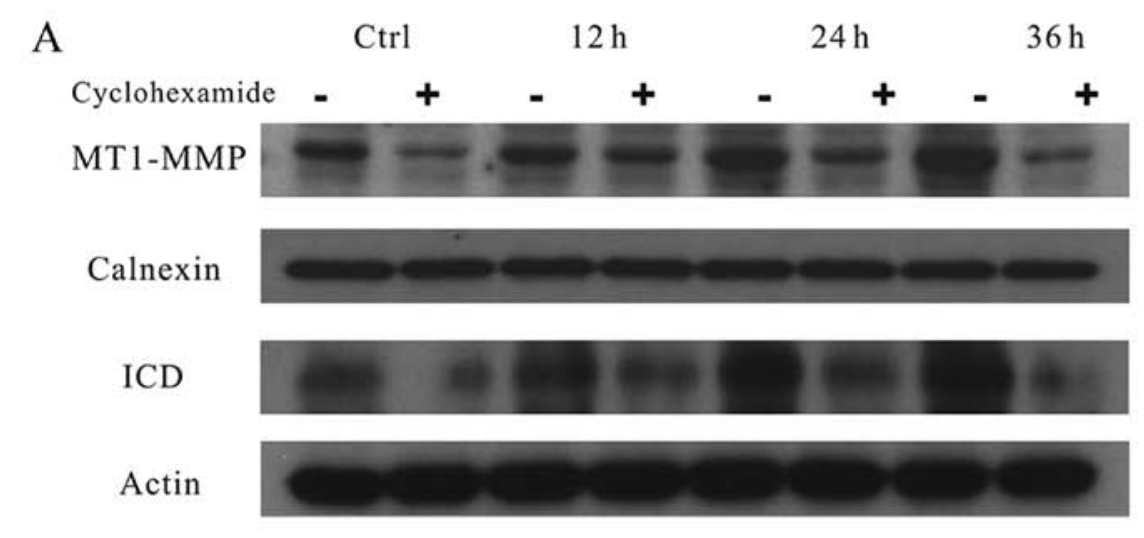

B

$\mathrm{C}$

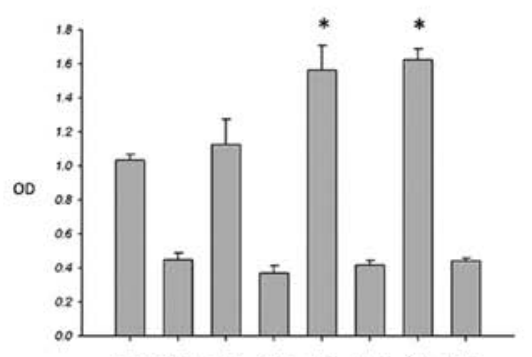

Ctrl Cetrl+ $12 \mathrm{~h} 12 \mathrm{~h}+24 \mathrm{~h} 24 \mathrm{~h}+36 \mathrm{~h} 36 \mathrm{~h}+$

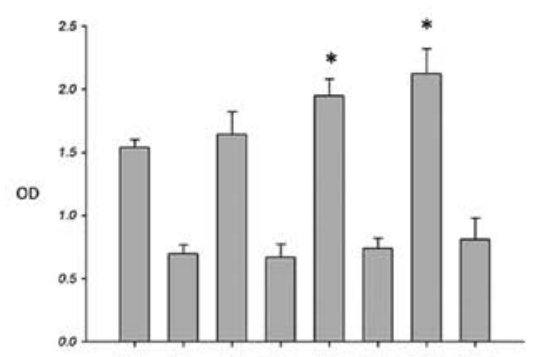

Ctrl Ctrl+ $12 \mathrm{~h} 12 \mathrm{~h}+24 \mathrm{~h} 24 \mathrm{~h}+36 \mathrm{~h} 36 \mathrm{~h}+$

D

\section{MT1-MMP}

\section{ICD}
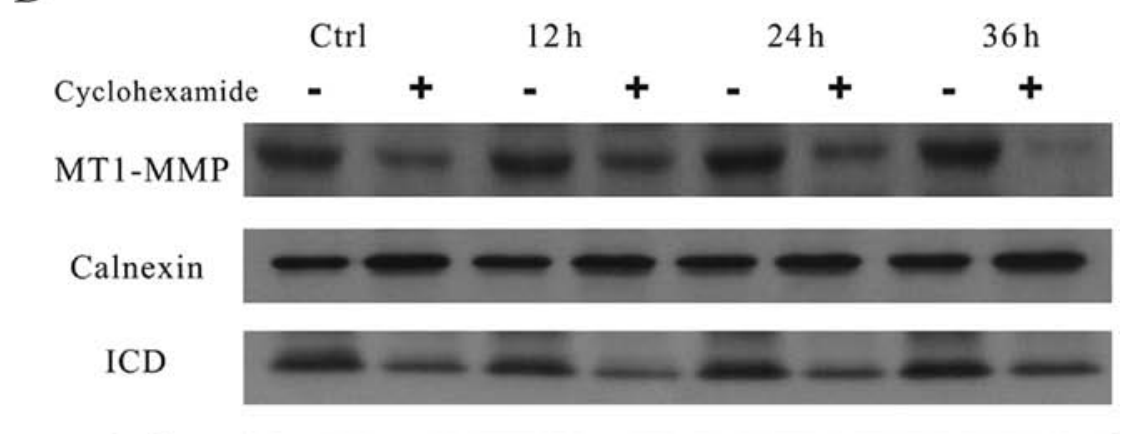

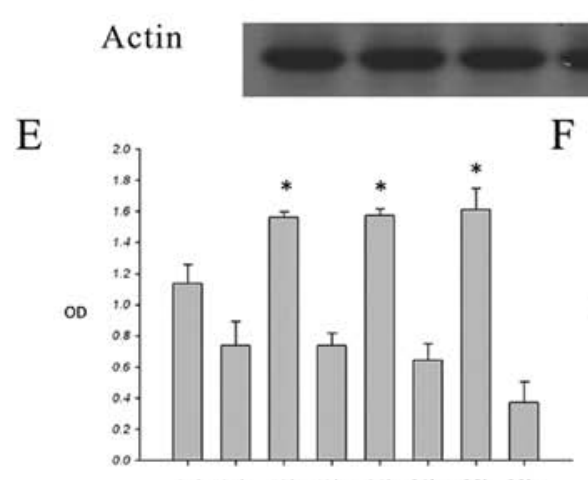

Ctrl Ctril $12 \mathrm{~h} 12 \mathrm{~h}+24 \mathrm{~h} 24 \mathrm{~h}+36 \mathrm{~h} 36 \mathrm{~h}+$
F

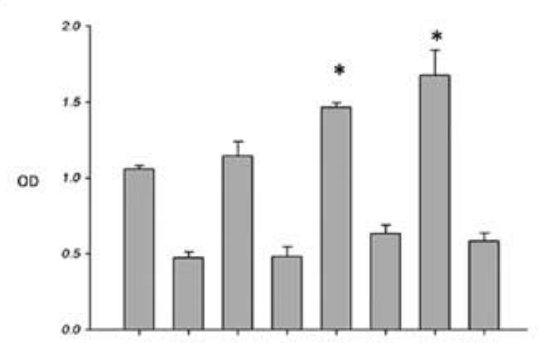

Cerl cerro $12 \mathrm{~h} 12 \mathrm{~h}+24 \mathrm{~h} 24 \mathrm{~h}+36 \mathrm{~h} 36 \mathrm{ht}$

Figure 4. Effect of cycloheximide in HA-induced MT1-MMP expression and CD44 cleavage in breast cancer cells. MDA-MB-435s and MDA-MB-231 cells were incubated in a serum-free medium for $3 \mathrm{~h}$ and then treated with a control medium or a medium with $6.5 \mathrm{kDa} \mathrm{HA}(0.5 \mathrm{mg} / \mathrm{ml})$ for different time periods as indicated. Cells were treated with a control medium or a medium with $6.5 \mathrm{kDa} \mathrm{HA}(0.5 \mathrm{mg} / \mathrm{ml})$ in the presence or absence of the translation inhibitor, cycloheximide $(20 \mu \mathrm{g} / \mathrm{ml}$, added $1 \mathrm{~h}$ before HA treatment). Cell lysates were analyzed by western blotting. MT1-MMP expression on the cell membrane was upregulated by HA treatment and was inhibited by adding cycloheximide in (A and B) MDA-MB-435s and (D and E) MDA-MB-231 cells. HA stimulation caused CD44 cleavage product ICDs to increase in both (A and C) MDA-MB-435s and (D and F) MDA-MB-231 cells. * $<0.05$ compared to the control.

tissues may enhance tumor invasion and metastasis. HA has been found to enhance tumor cell adhesion and migration (32) and to activate the Ras-mitogen-activated protein kinase and phosphoinositide 3-kinase pathways (33). These reports suggested that HA and/or its degradation products may be involved in the CD44 signaling that enhances tumor motility.

Although high and low molecular weight HA can induce different effects in the same cells, in most studies the size 
A

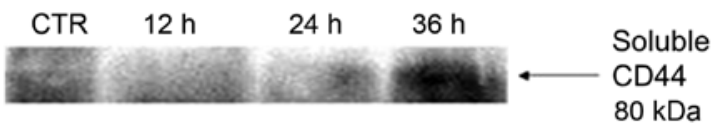

\section{B}

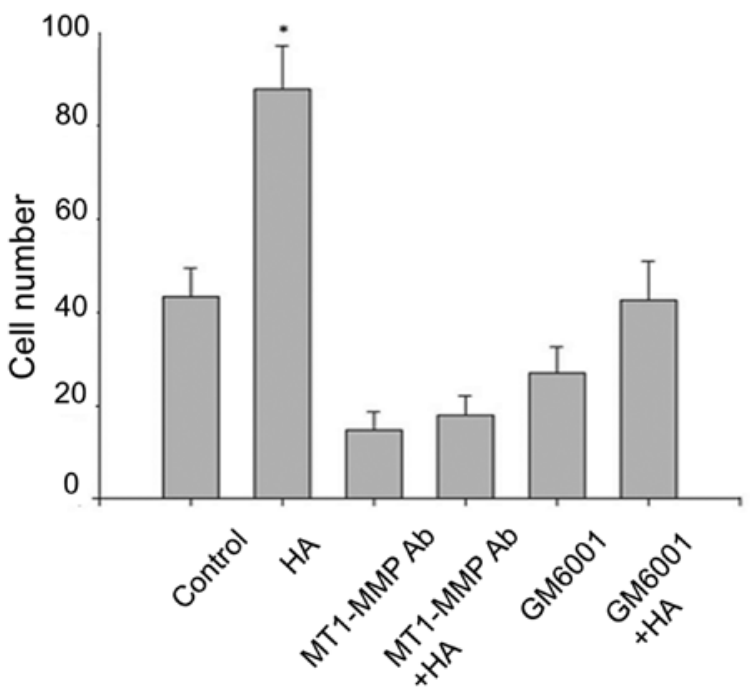

Figure 5. Effect of HA on CD44 cleavage and HA-induced cell migration. Soluble form CD44 caused by HA stimulation in the medium was analyzed by western blotting (A). Cells were treated with control medium or medium with $6.5 \mathrm{kDa} \mathrm{HA}(0.5 \mathrm{mg} / \mathrm{ml})$. After incubating cells under the indicated condition for different time periods, soluble form CD44 in the medium was analyzed by western blotting (A). Cells treated with control medium or medium containing HA $(10 \mathrm{ng} / \mathrm{ml})$ in the presence or absence of the MT1-MMP antibody $(10 \mu \mathrm{g} / \mathrm{ml})$ or MMP inhibitor GM6001 $(25 \mu \mathrm{M} / \mathrm{ml})$ were inoculated into the Matrigel-coated transwell. After incubation for $60 \mathrm{~h}$ at $37^{\circ} \mathrm{C}$, cells that had migrated into the lower wells were stained (Giemsa stain) and counted. Data are representative of 4 different experiments and are expressed as the means and SEM for the migrated breast cancer cells from 4 experiments.

of HA was not monitored. We found that by adding $6.5 \mathrm{kDa}$ and $5.6 \mathrm{kDa} \mathrm{HA}$ oligosaccharide to stimulate MDA-MB-435s cells, MT1-MMP expression was increased dramatically after $36 \mathrm{~h}$ of treatment, but not the $17 \mathrm{kDa} \mathrm{HA}$ oligosaccharide. Therefore, in further study, we used a $6.5 \mathrm{kDa}$ HA oligosaccharide. We also used real-time PCR to observe MT1-MMP mRNA expression and found that MT1-MMP mRNA may be detected after $1 \mathrm{~h}$ of HA stimulation and is maintained until $6 \mathrm{~h}$ of stimulation in MDA-MB-435s and MDA-MB-231 cells. To confirm that HA stimulation of MT1-MMP is conducted through protein synthesis, we pre-treated breast cancer cells with cycloheximide. The results of western blot analysis and flow cytometry both showed that HA-induced MT1-MMP expression was blocked by pre-treatment with cycloheximide. From the above experiments, we suggest that HA stimulation of MT1-MMP is conducted through protein synthesis.

CD44 is expressed in many types of metastatic tumor cells $(2,4,34)$. The soluble form CD 44 can be shed from cell surfaces through a proteolytic process (35). CD44 cleavage contributes to the regulation of CD44-HA interactions required for the migration process, and consequently promotes $\mathrm{CD} 44$-mediated cancer cell migration. This proteolytic cleavage of CD44 is involved in tumor invasion and metastasis (12). MT1-MMP appears to possess CD44 shedding capabilities and promotes cell migration (35). Moreover, MT1-MMP and CD44 were colocalized at the migration front, which is important in cell migration (35). CD44H has been found to link MT1-MMP to the cytoskeleton and regulate its localization (36). This interaction is critical for the shedding of $\mathrm{CD} 44 \mathrm{H}$ and the cell migration (36). MT1-MMP appears to possess CD44 shedding capabilities and promotes cell migration as demonstrated by the colocalization of MT1-MMP and CD44, which is important for cell migration (11). Accumulating evidence suggests that MT1-MMP plays a pivotal role in tumor cell migration and invasion (36-38). In this study, we found that CD44 is colocalized with HA-induced MT1-MMP on the cell membrane. After $24 \mathrm{~h}$ of HA stimulation, there was a marked increase in the ICD of CD44.

These results suggest that $6.5 \mathrm{kDa} \mathrm{HA}$ oligosaccharide stimulation of human breast cancer cells induces the expression of MT1-MMP, and that MT1-MMP and CD44 were colocalized on the cell surface which further causes CD44 cleavage. CD44 cleavage has been demonstrated to play a critical role in CD44-mediated tumor cell migration by providing offsetting changes in adhesive interactions between CD44 and extra cellular matrix $(9,39)$. In order to analyze the correlation between HA stimulation of MT1-MMP expression, CD44 cleavage and breast cancer cell mobility, we used Matrigelcoated transwell to observe tumor cell migration. After $60 \mathrm{~h}$ of HA stimulation, there was a clear increase in the invasive capabilities of the stimulated cells, and this migration may be inhibited by specific anti-MT1-MMP Ab or MMP inhibitors.

MMP-1, -2,-9 and MT1-MMP are involved in cancer invasion (40). Membrane type 1-MMP degrades the extracellular matrix, activating other MMPs (18), and acts as a shedding enzyme involving CD44 cleavage and promotes the cell movement $(10,35)$. Through tissue staining it has been found that invasive breast cancer cells have higher levels of CD44 than normal tissue $(2,41)$. In the present study, we demonstrated that $6.5 \mathrm{kDa} \mathrm{HA}$ oligosaccharide stimulation of the human breast cancer cell lines MDA-MB-435s and MDA-MB-231 was able to induce the expression of MT1-MMP through protein synthesis. Our data also suggest that HA-induced MT1-MMP and CD44 are colocalized on the cell surface and that CD44 showed signs of cleavage. A significant increase in the invasive capabilities of HA-stimulated breast cancer cells was observed using the migration assay. These observations indicate that HA induced MT1-MMP expression, which then caused CD44 cleavage and thus enhanced the invasive abilities of the cancer cells. We believe that the results of this study yield significant insight into breast cancer invasion and metastasis. In conclusion, we found that HA oligosaccharideinduced MT1-MMP expression in breast cancer cells may be an element of the sequence of molecular events preceding metastasis.

\section{Acknowledgements}

This study was supported by a research grant from the National Science Council, Taiwan (NSC 95-2320-B-010-036-MY2, NSC 97-2320-B-010-019-MY3) and a grant from the Ministry of Education, Aim for the Top University Plan to H.S.W. 


\section{References}

1. Lesley L, Hyman R and Kincade PW: CD44 and its interaction with extracellular matrix. Adv Immunol 54: 271-335, 1993.

2. Naor D, Sionov RV and Ish-Shalom D: CD44: structure, function, and association with the malignant process. Adv Cancer Res 71: 241-319, 1997.

3. Shimizu Y, Van Seventer GA, Siraganian R, et al: Dual role of the CD44 molecule in T cell adhesion and activation. J Immunol 143: 2457-2463, 1989.

4. Gunthert U, Hofmann M, Rudy W, et al: A new variant of glycoprotein CD44 confers metastatic potential to rat carcinoma cells Cell 65: 13-24, 1991

5. Screaton GR, Bell MV, Jackson DG, et al: Genomic structure of DNA encoding the lymphocyte homing receptor CD44 reveals at least 12 alternatively spliced exons. Proc Natl Acad Sci USA 89 12160-12164, 1992.

6. Underhill CB: CD44: the hyaluronan receptor. J Cell Sci 103: 293-298, 1992.

7. Liotta LA: Tumor invasion and metastases - role of the extracellular matrix: Rhoads Memorial Award Lecture. Cancer Res 46 1-7, 1986.

8. Guo UJ, Ma J, Wang J, et al: Inhibition of human melanoma growth and metastasis in vivo by anti-CD44 monoclonal antibody. Cancer Res 54: 1561-1565, 1994.

9. Zahalka MA, Okon E, Gosslar U, et al: Lymph node (but not spleen) invasion by murine lymphoma is both CD44- and hyaluronate-dependent. J Immunol 154: 5345-5355, 1995.

10. Okamoto I, Kawano Y, Tsuiki H, et al: CD44 cleavage induced by a membrane-associated metalloprotease plays a critical role in tumor cell migration. Oncogene 18: 1435-1446, 1999.

11. Zhong J, Cornelsen Gencay MM, Bubendorf L, et al: ERK1/2 and p38 MAP kinase control MMP-2, MT1-MMP, and TIMP action and affect cell migration: a comparison between mesothelioma and mesothelial cells. J Cell Physiol 207: 540-552, 2006.

12. Okamoto I, Kawano Y, Murakami D, et al: Proteolytic release of CD44 intracellular domain and its role in the CD44 signaling pathway. J Cell Biol 155: 755-762, 2001

13. Mignatti $P$ and Rifkin DB: Biology and biochemistry of proteinases in tumor invasion. Physiol Rev 73: 161-195, 1993.

14. Nagase H and Woessner JF Jr: Matrix metalloproteinases. J Biol Chem 274: 21491-21494, 1999.

15. Seiki M: Membrane-type matrix metalloproteinases. APMIS 107: 137-143, 1999.

16. Hiraoka N, Allen E, Apel IJ, et al: Matrix metalloproteinases regulate neovascularization by acting as pericellular fibrinolysins. Cell 95: 365-377, 1998.

17. Galvez BG, Matias-Roman S, Albar JP, et al: Membrane type 1-matrix metalloproteinase is activated during migration of human endothelial cells and modulates endothelial motility and matrix remodeling. J Biol Chem 276: 37491-37500, 2001.

18. Egeblad M and Werb Z: New functions for the matrix metalloproteinases in cancer progression. Nat Rev Cancer 2: 161-174, 2002.

19. Sato H, Takino T, Okada Y, et al: A matrix metalloproteinase expressed on the surface of invasive tumour cells. Nature 370 : 61-65, 1994.

20. Knauper V, Will H, Lopez-Otin C, et al: Cellular mechanisms for human procollagenase-3 (MMP-13) activation. Evidence that MT1-MMP (MMP-14) and gelatinase a (MMP-2) are able to generate active enzyme. J Biol Chem 271: 17124-17131, 1996.

21. Kuo YC, Su CH, Liu CY, et al: Transforming growth factor-beta induces CD44 cleavage that promotes migration of MDA-MB435s cells through the up-regulation of membrane type 1-matrix metalloproteinase. Int J Cancer 124: 2568-2576, 2009.
22. Seiki M: The cell surface: the stage for matrix metalloproteinase regulation of migration. Curr Opin Cell Biol 14: 624-632, 2002.

23. Okada Y: Tumor cell-matrix interaction: pericellular matrix degradation and metastasis. Verh Dtsch Ges Pathol 84: 33-42, 2000.

24. Laurent TC and Graser JR: Hyaluronan. FASEB J 6: 2397-2404, 1992.

25. Balazs EA, Watson D, Duff IF, et al: Hyaluronic acid in synovial fluid. I. Molecular parameters of hyaluronic acid in normal and arthritis human fluids. Arthritis Rheum 10: 357-376, 1967.

26. Dahl IM and Laurent TC: Concentration of hyaluronan in the serum of untreated cancer patients with special reference to patients with mesothelioma. Cancer 62: 326-330, 1988.

27. Kumar S, West DC, Ponting JM, et al: Sera of children with renal tumours contain low-molecular-mass hyaluronic acid. Int J Cancer 44: 445-448, 1989.

28. Lokeshwar VB, Obek C, Soloway MS, et al: Tumor-associated hyaluronic acid: a new sensitive and specific urine marker for bladder cancer. Cancer Res 57: 773-777, 1997.

29. West DC, Hampson IN, Arnold F, et al: The effect of hyaluronate and its oligosaccharides on endothelial cell proliferation and monolayer integrity. Science 228: 1324-1326, 1985.

30. Lokeshwar VB, Rubinowicz D, Schroeder GL, et al: Stromal and epithelial expression of tumor markers hyaluronic acid and HYAL1 hyaluronidase in prostate cancer. J Biol Chem 276: 11922-11932, 2001

31. Pham JT, Blick NL and Lokeshwar VB: Tumor-derived hyaluronidase: a diagnostic urine marker for high-grade bladder cancer. Cancer Res 57: 778-783, 1997.

32. Itano N, Atsumi F, Sawai T, et al: Abnormal accumulation of hyaluronan matrix diminishes contact inhibition of cell growth and promotes cell migration. Proc Natl Acad Sci USA 99: 3609-3614, 2002.

33. Sohara $\mathrm{Y}$, Ishiguro $\mathrm{N}$, Machida $\mathrm{K}$, et al: Hyaluronan activates cell motility of v-Src-transformed cells via Ras-mitogen-activated protein kinase and phosphoinositide 3-kinase-Akt in a tumorspecific manner. Mol Biol Cell 12: 1850-1868, 2001.

34. Sneath RJ and Mangham DC: The normal structure and function of CD44 and its role in neoplasia. Mol Pathol 51: 191-200, 1998.

35. Kajita M, Itoh Y, Chiba T, et al: Membrane-type 1 matrix metalloproteinase cleaves CD44 and promotes cell migration. J Cell Biol 153: 893-904, 2001.

36. Mori H, Tomari T, Koshikawa N, et al: CD44 directs membranetype 1 matrix metalloproteinase to lamellipodia by associating with its hemopexin-like domain. EMBO J 21: 3949-3959, 2002.

37. Ueda J, Kajita M, Suenaga N, et al: Sequence-specific silencing of MT1-MMP expression suppresses tumor cell migration and invasion: importance of MT1-MMP as a therapeutic target for invasive tumors. Oncogene 22: 8716-8722, 2003.

38. Annabi B, Bouzeghrane M, Moumdjian R, et al: Probing the infiltrating character of brain tumors: inhibition of RhoA/ ROK-mediated CD44 cell surface shedding from glioma cells by the green tea catechin EGCg. J Neurochem 94: 906-916, 2005.

39. Goebeler M, Kaufmann D, Brocker EB, et al: Migration of highly aggressive melanoma cells on hyaluronic acid is associated with functional changes, increased turnover and shedding of CD44 receptors. J Cell Sci 109: 1957-1964, 1996.

40. Hotary K, Allen E, Punturieri A, et al: Regulation of cell invasion and morphogenesis in a three-dimensional type I collagen matrix by membrane-type matrix metalloproteinases 1,2 , and 3 . J Cell Biol 149: 1309-1323, 2000.

41. Iida N and Bourguignon LY: New CD44 splice variants associated with human breast cancers. J Cell Physiol 162: 127-133, 1995. 